\title{
ATTEMPT TO THE EMPLOYEE SATISFACTIONS IN THE PRIVATE FIRMS WITHIN THE PHARMACY INDUSTRY IN INDONESIA: ROOTING FROM THE GOAL- SETTING THEORY AND ITS CONTRIBUTION
}

\author{
Nisa Nurul Afiah ${ }^{1}$, Ruth Adriana ${ }^{2}$ and Wilhelmus Hary Susilo*3 \\ Postgraduate $^{1-2}$, Faculty of Business and Management, University of Persada Indonesia Y.A.I
}

DOI: http://dx.doi.org/10.38193/IJRCMS.2021.3502

\begin{abstract}
The scholars found that the Pharmacy firms in industries competitiveness had less an employee satisfaction within these global pandemic situations. This research could be study among research gap within the employee- factors within the pharmacy industry in Indonesia and impact by the firm's performance. Moreover, the novelty result of the model of the attempt of an employee- satisfaction and its contribution on body of knowledge on theory of goal setting theory. Hence, the research method conducted within quantitative and the predicted strategy and the data analysis within an entire the latent variables to attempt the employee satisfaction. The results were contribution to the body of knowledge the management science on the theory of GST and the Pharmacy industries in Indonesia.
\end{abstract}

KEYWORDS: Employee satisfaction, employee performance, GST, Pharmacy industry.

\section{INTRODUCTION}

The Pharmacy firm's development could deliver a large-scale of industrial modern that it would of the demand size requirements from among consumers and determine the large-social network. (Kjos, Worley, \& Schommer, 2013) (Derwik, Hellström, \& Karlsson, 2016) Moreover, the key highlight of the pharmacy industries in Indonesia to improve the organizational performance pertains; the leadership, innovation management, faster innovation and link to the global networking and also aware to consumer engagement base on the employee satisfaction. (J. Hamilton, 2009) (Akdoğan \& Durak, 2016; Gupta, Singh, \& Bhattacharya, 2017; Gürcan, Yazıc1, Beyca, Arslan, \& Eldemir, 2016)

Indeed, Industry Minister, Agus Gumiwang Kartasasmita, claimed 220 ventures support the pharmaceutical industry in Indonesia; and 90\% focus on the downstream in producing medicines. Moreover, the government to strive to reduce imports by $35 \%$ by the end of 2022 . Hence, the country would overcome dependence on raw material imports and the statistics data from the ministry of investment RI, show figure 1 below: 


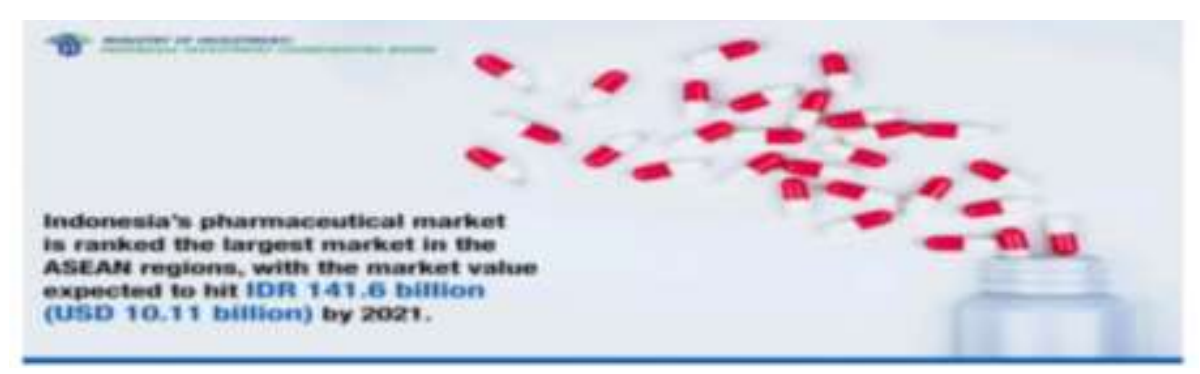

\section{Figure 1. The Pharmacy Industries within domestics- Indonesia \\ (Resource: https://www.bkpm.go.id/en/publication/detail/news/winning-potentials-in-indonesian-pharma-and-medical-industries)}

The Pharmacy industries and business in the global- pandemic situations within the dynamic- market, need more, the communications tools, hi-competencies, regularly of the skill training, and organizational-well mechanism and, the new platform in the pharmacy business as the research gaps from the previous research that could leads to the human resources development within the employee satisfaction, that have been could not always to be confirm result of the research on the Pharmacy venture (J. Hamilton, 2009) (Harrigan, Evers, Miles, \& Daly, 2017; Moharam \& Shawky, 2012; Syed Saad, Mamunur, \& Quazi Akhlaqur, 2016), (Bitter \& Grabner-Kräuter, 2016; Day, Crown, \& Ivany, 2017)

Moreover, to fill this gap, many pharmacy firms have the organizational policy-change become the new-platform business cause to anticipated the global- pandemic in business world within very poorbusiness process of the impact to the employee intellectual capital-performance (Day et al., 2017; Kor, 2016; Stock, 2016; Tse, Huang, \& Lam, 2013; Ulum, Ghozali, \& Purwanto, 2014). Furthermore, the objective of these inquiries would be conduct within the synthesis the HR management new- research model to fulfilling the find of research gap to achieve the employee satisfaction in the pharmacy industry in Indonesia. Moreover, the focus of the latent variables as develop to leads the employee satisfaction in the Pharmacy firms- business management within the new platform business for a long run business competitiveness.(Buil, Catalán, \& Martínez, 2016; Demirkan \& Spohrer, 2014; Geraerdts, 2012; Järvinen \& Karjaluoto, 2015; Kasper-Brauer \& Leischnig, 2016; Kianto, Sáenz, \& Aramburu, 2017; Kim, Cavusgil, \& Cavusgil, 2013; Landroguez, 2013; Li, 2010; Malik, Pereira, \& Budhwar, 2017; Matošková \& Směšná, 2017; Mention \& Bontis, 2013; Nicole, Vaughan, Zabihullah, \& Mei, 2016; Obal \& Lancioni, 2013; Ouakouak \& Ouedraogo, 2017; Pittino, Visintin, Lenger, \& Sternad, 2016; Rakesh, Narendra, \& Sandeep, 2017; Senichev, 2013; Stone, Deadrick, Lukaszewski, \& Johnson, 2015; Walmsley, 2016; Xerri \& Reid, 2017)

The Pharmacy firms- business within on the new platform business management to anticipated the global pandemic phenomenon, the source of employee value an entire firms should have some strategic plan and not implement in the same time for many to pursue an employee- satisfaction, and 
the human resources- advantage on among market- position for having the new- opportunity within the new platform- business to gain the profit embedded that conducted to create an consumer- smart value within the among enterprises'. (Chaouali, Souiden, \& Ladhari, 2017; Cicekli, 2016; Kjos et al., 2013; Lee, 2009; Szopiński, 2016)

Furthermore, the business plan choices on the pharmacy industries for making the improvement of the firms- business management within an employee- satisfaction and a large of the social network, great employee value- creation also the supported to employee- skill and aware a spirit and also the well mechanism among pharmacy firm in Indonesia. (Bravo, Matute, \& Pina, 2015; Kang \& Lam, 2016; Kjos et al., 2013; Mullen, Kelloway, \& Teed, 2017; Raybould \& Wilkins, 2006; Sambasivan, Abdul, \& Yusop, 2009). (R. T. Hamilton, 2011; Poisson-de Haro \& Bitektine, 2015; Reid \& Brady, 2012; Z. Wang, Sharma, \& Cao, 2016)(Aima, Susilo, Purwanto and Wiratih, 2015).

\section{Literature review and the Hypothesis}

The scientist have to study of the research- HR- management model to attempt an employee satisfaction within the pharmacy industries that it was conducted within the contributions for the body of knowledge on GST for improve employee job- satisfaction for the competitions, but also for the giving the contributions of the management and business implications to make the venture-strategies within among the Pharmacy Firms to improve well- the business plan for the long- run in business activities within the new platform in Pharmacy business and the agile- management practice on the business-competitiveness in Indonesia.(J. Hamilton, 2009) (Ashill, Rod, \& Gibbs, 2015; Augusto \& Torres, 2018; Catania, 2014; Corsaro, Ramos, Henneberg, \& Naudé, 2011; Csikósová, Čulková, \& Janošková, 2016; del Alonso-Almeida, Bagur-Femenías, \& Llach, 2013; Deschamps \& Mattijs, 2017).

Furthermore, in this study for doing the mapping the entire firms in the competitiveness advantage in the Pharmacy Firms in Indonesia that it's would impacts from enhancing the performance in Pharmacy industries and business for the long- run and should anticipated the global pandemic situations within the new business- platform and ethical consequences. (Bouskila-Yam \& Kluger, 2011; Estrada, Faems, \& de Faria, 2016; Ivens, Pardo, Niersbach, \& Leischnig, 2016; Kjos et al., 2013; D. Welsh, Bush, Thiel, \& Bonner, 2019).

The Rooting from The Goal Setting Theory and the Management Science of the Body of Knowledge The scientist would like to rooted from the GST for develop business strategies in the Pharmacy industries for many heterogeneously industries for increased the well employee satisfaction and performance thought the and well stepping-training (Bravo et al., 2015; Fink, Yogev, \& Even, 2016; Gómez-Miñambres, 2012; Ivanova \& Ivanov, 2015). Hence, the distinctive work competence within entire employee and the general managers of the pharmacy firms could help the firms for facing its competitions and the global pandemics' situations in many industries. (Hult, Ketchen Jr, \& Reus, 
2001; Javad Khazaei, Masood, \& Ezat Amirbakzadeh, 2017; Locke, 1996; Mitrega, 2012).

Moreover, the R-A theory have competition among firm in heterogeneous business in the Pharmacy industries firms- venture organizational performance and the sustainable competitive advantage should have as the foundation of the firms to create the best policy and the new-platform in business management, bundles the building employee- engagement and networking, and for achieving the employee satisfaction and performance within the top- managers supported within the organizationalstructure. (Alisher Tohirovich, Changjoon, \& Junghyun, 2017; Gabrielsson, Seppälä, \& Gabrielsson, 2016; J. Hamilton, 2009; Shelby D. Hunt, 2013, 2015; Shelby D Hunt \& Morgan, 1995; Krausert, 2017; Kumar \& Yakhlef, 2016; G. P. Latham, 2016; Nahrgang et al., 2013; Nor Shahriza Abdul, Mohamed Jalaldeen Mohamed, \& Norshidah, 2012; Stan De, Monique, \& Guy Van, 2017; C.-J. Wang, Tsai, \& Tsai, 2014; Xiaohong, Chengfeng, Yanbo, \& Gaowen, 2015; Zhao, Feng, \& Wang, 2015)

The researcher would be rooting to the GST theory to fulfill the research gap within the Pharmacy industry-firms and it could contribute to evolve for the body of the business science and result the novelty of the research result from empirical research for the employee satisfaction within the pharmacy firms in Indonesia, as follow, the figure 2 below (Chang, Jiang, Klein, \& Wang, 2019; Landers, Bauer, \& Callan, 2017; G. Latham, Seijts, \& Slocum, 2016; G. P. Latham, 2003):

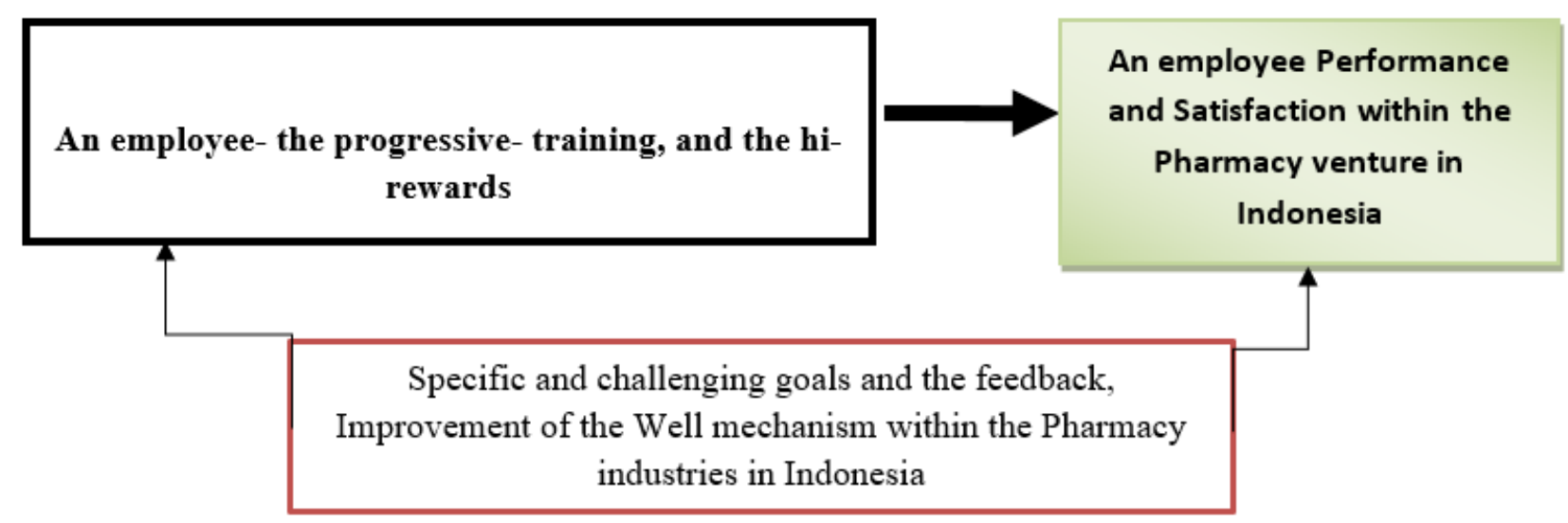

Figure 2. The Goal-setting Theory for evolved the body of business-science as the empirical management- HR- development research

\section{The Framework and Hypothesis}

The research framework of achievement on the employee satisfaction within the Pharmacy Industries in Indonesia would be to develop for fulfillment the research gap for finding the knowledge to improvement the employee satisfaction. (Chang et al., 2019; Chiang \& Birtch, 2010; Gupta et al., 
2017; Kjos et al., 2013; Mohamed, 2016; Munir, Rahman, Malik, \& Ma'amor, 2012; Silva, Gerwe, \& Becerra, 2017).

Furthermore, the research- framework to improve an employee satisfaction within the Pharmacy firms in Indonesia, as follow figures 3, below (J. Hamilton, 2009; Kjos et al., 2013):

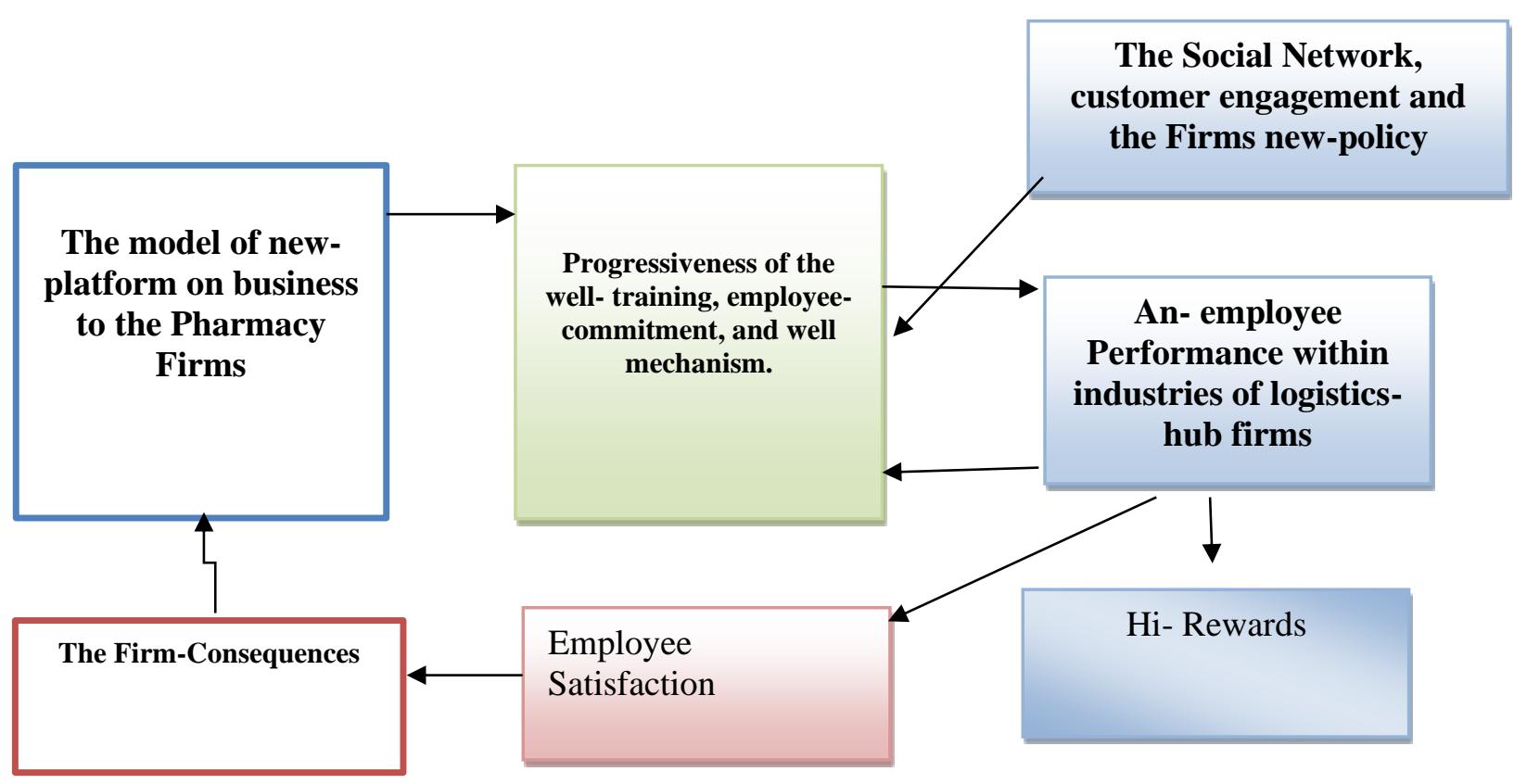

Fig.3. The Research Model of Improve an Employee Satisfaction on The Pharmacy Industry in Indonesia

The hypothesis in these inquiries the conceptual research model of an Achievement to the Employeesatisfaction of the Firms of Pharmacy Industries in Indonesia, as follow (Ford, 2017; Kjos et al., 2013; D. T. Welsh \& Ordóñez, 2014; Xu, Wang, \& Wen, 2019):

H1: The antecedents employee factors positively related to the distinctive- employee satisfaction that its model would drive by the social network, customer engagement and new-firm policy as the moderating on the Pharmacy industries in Indonesia.

\section{Research method}

\section{The respondent, and how data collection}

The population and determining of the sample frame as the target populations for this research conducted within clustered- random sampling technique within among officially- employee to be selected of the Pharmacy firms in Indonesia as a unit analysis. (Borenstein, Hedges, Higgins, \& 
Rothstein, 2009; Hertwig \& Pleskac, 2010; Mathwick, Wagner, \& Unni, 2010; Susilo, 2020b; Thomas, 2013; Vos, Schiele, \& Hüttinger, 2016).

Moreover, the field research survey would conduct by the self-administered questionnaire (S-AQ) that it would measures within the rating scale (1 to 10 rating independently scale) to the among latent variables to make the response for distinctive- employee satisfaction of among the pharmacy firms (Samson, Gloet, \& Singh, 2017; Stundziene, Startiene, Remeikiene, \& Dapkus, 2015; Susilo, 2020a) (Sekaran and Bougie, 2016).

Moreover, the test of the validity and reliability of entire latent- variables analyzed and also the research- HR development model should have the goodness of fitting within the fitting- standard of SEM, the confirmatory factor analysis modeling that conducted to the measurement model and the structural equation modeling phase of the ordering, among the latent variables and its dimensions as the second order research-model and also the goodness of fit indexes modeling (Agostini, Nosella, \& Filippini, 2016; Ghozali, 2013; Jangl, 2016; Susilo, 2020a) (Hair, Black, Babin and Anderson, 2010)(Evermann \& Tate, 2016).

\section{Data analysis}

\section{The Hypothesis testing}

The new concept research-model in this study that pursue the well-employee satisfaction on the pharmacy- firms should be conduct to the structural equation modeling; an entire the latent constructs were un-observed characteristics. (Susilo, 2020b) Furthermore, the two phase approach will encompasses; the measurement model and the structural of the full model that conducted to the confirmatory strategies in this multivariate data analysis, the fitting model and hypothesis confirmed to the research model (Ghozali, 2013; Susilo, 2020b)(Susilo and Yulius, 2017).

Hence, the research result to attempt the well- employee satisfaction will gain for the data analysis pertain: the sensitivity analysis: the test indicated did not have the outlier and missing value that conducted with SPSS and the $\mathrm{z}$ value $<4.00$ and the multivariate of normality test (Susilo, 2020b).

Therefore, the goodness of fit research HR- Development model in this investigated will be analyze within the entire an incremental- indexed value (Susilo, 2020a). Moreover, the entire hypothesis confirmed with $t$ value $>2.00$, on the path- hybrid t-model and the structural equations modeling on HR- development model to achieve the employee satisfaction. (Augusty, 2014; Susilo, 2016, 2020b)

\section{Conclusions and research contribution.}

Actually, the scholars will be to the fulfillment the research gap within the new research model would effectively to achieve the employee- satisfaction on the pharmacy firms in Indonesia. Furthermore, 
the research contributions were within 2 (two) area that pertain; first, the contributions for theoretical implications to the body of management science of the resources advantage in human resource management of the pharmacy venture in Indonesia. Further, the result research will root with the Goal setting Theory as the explanations and confirmed the relationship for the pursue the distinctiveemployee-satisfaction that it's would inquiries on the increased of an well mechanism-employee, that have the well supported from among the new policy base on the management of human resources science to the future evolved.

\section{Acknowledgement}

Thank you so much to the Expertise and Experience Learning Club, Faculty of Business and Management, University of Persada Indonesia Y.A.I. To my colleague and students. To In Kind Workshops NEW E\&EL CLUB LABORATORY FEB UPI Y.A.I team.

Declaration of conflicting interests

The scholar declared no potential conflicts of interest with respect to the investigated, authorship, publication within this manuscript.

Funding

The authors did not receive the financial support for this research and publication of this manuscript.

ORCID:000-0002-6758-1159, URL: orcid.org/0000-0002. And SCOPUS ID: 56539508300.

\section{REFERENCES}

Agostini, L., Nosella, A., \& Filippini, R. (2016). Towards an Integrated View of the Ambidextrous Organization: A Second-Order Factor Model. Creativity and Innovation Management, 25(1), 129-141. doi: 10.1111/caim.12167

Akdoğan, M. Ş., \& Durak, A. (2016). Logistic and Marketing Performances of Logistics Companies: A Comparison between Germany and Turkey. Procedia - Social and Behavioral Sciences, 235, 576-586. doi: 10.1016/j.sbspro.2016.11.084

Alisher Tohirovich, D., Changjoon, R., \& Junghyun, Y. (2017). Organizational structure and innovation performance: Is employee innovative behavior a missing link? Career Development International, 22(4), 334-350. doi: 10.1108/CDI-12-2016-0234

Ashill, N. J., Rod, M., \& Gibbs, T. (2015). Coping with stress: A study of retail banking service workers in Russia. Journal of Retailing and Consumer Services, 23, 58-69. doi: 10.1016/j.jretconser.2014.12.006

Augusto, M., \& Torres, P. (2018). Effects of brand attitude and eWOM on consumers' willingness to pay in the banking industry: Mediating role of consumer-brand identification and brand equity. Journal of Retailing and Consumer Services, 42, 1-10. doi: 10.1016/j.jretconser.2018.01.005

Augusty, F. (2014). Structural Equation Modelling Dalam Penelitian Manajemen: Fakultas Ekonomi dan Bisnis Universitas Diponegoro.

Bitter, S., \& Grabner-Kräuter, S. (2016). Consequences of customer engagement behavior: when negative Facebook posts have positive effects. ElectronMarkets, 26, 13. 
Borenstein, M., Hedges, L. V., Higgins, J. P. T., \& Rothstein, R. R. (2009). Fixed-effect vs Randomeffects Introduction to Meta Analysis: Johnn Willey and Sons.

Bouskila-Yam, O., \& Kluger, A. N. (2011). Strength-based performance appraisal and goal setting. Human Resource Management Review, 21(2), 137-147. doi: 10.1016/j.hrmr.2010.09.001

Bravo, R., Matute, J., \& Pina, J. M. (2015). Corporate identity management in the banking sector: effects on employees' identification, identity attractiveness, and job satisfaction. Service Business, 10(4), 687-714. doi: 10.1007/s11628-015-0287-9

Buil, I., Catalán, S., \& Martínez, E. (2016). The importance of corporate brand identity in business management: An application to the UK banking sector. BRQ Business Research Quarterly, 19(1), 3-12. doi: 10.1016/j.brq.2014.11.001

Catania, G. (2014). The Unintended Consequences of Motivational Techniques: Goal Setting and Unethical Behavior in the Maltese Financial Services Industry. Procedia - Social and Behavioral Sciences, 109, 1375-1385. doi: 10.1016/j.sbspro.2013.12.640

Chang, J. Y. T., Jiang, J. J., Klein, G., \& Wang, E. T. G. (2019). Enterprise system programs: Goal setting and cooperation in the integration team. Information \& Management, 56(6). doi: 10.1016/j.im.2018.12.005

Chaouali, W., Souiden, N., \& Ladhari, R. (2017). Explaining adoption of mobile banking with the theory of trying, general self-confidence, and cynicism. Journal of Retailing and Consumer Services, 35, 57-67. doi: 10.1016/j.jretconser.2016.11.009

Chiang, F. F. T., \& Birtch, T. A. (2010). Pay for performance and work attitudes: The mediating role of employee-organization service value congruence. International Journal of Hospitality Management, 29(4), 632-640. doi: 10.1016/j.ijhm.2009.11.005

Cicekli, E. (2016). Graduate skills requirements for effective performance

in the banking sector. Verslas: teorija ir praktika, 17(4), 317-324. doi: 10.3846/btp.17.11127

Corsaro, D., Ramos, C., Henneberg, S. C., \& Naudé, P. (2011). Actor network pictures and networking activities in business networks: An experimental study. Industrial Marketing Management, 40(6), 919-932. doi: 10.1016/j.indmarman.2011.06.028

Csikósová, A., Čulková, K., \& Janošková, M. (2016). Evaluation of quantitative indicators of marketing activities in the banking sector. Journal of Business Research, 69(11), 5028-5033. doi: 10.1016/j.jbusres.2016.04.075

Day, A., Crown, S. N., \& Ivany, M. (2017). Organisational change and employee burnout: The moderating effects of support and job control. Safety Science. doi: 10.1016/j.ssci.2017.03.004

del Alonso-Almeida, M. M., Bagur-Femenías, L., \& Llach, J. (2013). The adoption of quality management practices and their impact on business performance in small service companies: the case of Spanish travel agencies. Service Business, 9(1), 57-75. doi: 10.1007/s11628-0130218-6 
ISSN 2582-2292

Vol. 3, No. 05 Sep-Oct; 2021

Demirkan, H., \& Spohrer, J. (2014). Developing a framework to improve virtual shopping in digital malls with intelligent self-service systems. Journal of Retailing and Consumer Services, 21(5), 860-868. doi: 10.1016/j.jretconser.2014.02.012

Derwik, P., Hellström, D., \& Karlsson, S. (2016). Manager competences in logistics and supply chain practice. Journal of Business Research, 69(11), 4820-4825. doi: 10.1016/j.jbusres.2016.04.037

Deschamps, C., \& Mattijs, J. (2017). Sustainable goal setting: a large-scale case in management practice. International Journal of Productivity and Performance Management, 66(8), 10871104. doi: 10.1108/IJPPM-05-2016-0100

Estrada, I., Faems, D., \& de Faria, P. (2016). Coopetition and product innovation performance: The role of internal knowledge sharing mechanisms and formal knowledge protection mechanisms. Industrial Marketing Management, 53, 56-65. doi: 10.1016/j.indmarman.2015.11.013

Evermann, J., \& Tate, M. (2016). Assessing the predictive performance of structural equation model estimators. Journal of Business Research, 69(10), 4565-4582. doi: 10.1016/j.jbusres.2016.03.050

Fink, L., Yogev, N., \& Even, A. (2016). Business intelligence and organizational learning: An empirical investigation of value creation processes. Information \& Management. doi: 10.1016/j.im.2016.03.009

Ford, R. C. (2017). Combining performance, learning, and behavioral goals to match job with person: Three steps to enhance employee performance with goal setting. Business Horizons, 60(3), 345-352. doi: 10.1016/j.bushor.2016.12.001

Gabrielsson, M., Seppälä, T., \& Gabrielsson, P. (2016). Realizing a hybrid competitive strategy and achieving superior financial performance while internationalizing in the high-technology market. Industrial Marketing Management, 54, 141-153. doi: 10.1016/j.indmarman.2015.07.001

Geraerdts, R. (2012). Customer value creation: A journey in the search of excellence. Industrial Marketing Management, 41(1), 11-12. doi: 10.1016/j.indmarman.2011.11.023

Ghozali, I. (2013). Model Persamaan Structural, Konsep dan Aplikasi Dengan Program AMOS 21.0: Badan Penerbit Universitas Diponegoro.

Gómez-Miñambres, J. (2012). Motivation through goal setting. Journal of Economic Psychology, 33(6), 1223-1239. doi: 10.1016/j.joep.2012.08.010

Gupta, V., Singh, S., \& Bhattacharya, A. (2017). THE RELATIONSHIPS BETWEEN LEADERSHIP, WORK ENGAGEMENT AND EMPLOYEE INNOVATIVE PERFORMANCE: EMPIRICAL EVIDENCE FROM THE INDIAN R\&D CONTEXT. International Journal of Innovation Management, 21(07), 1750055. doi: 10.1142/S1363919617500554 
ISSN 2582-2292

Vol. 3, No. 05 Sep-Oct; 2021

Gürcan, Ö. F., Yazıcı, İ., Beyca, Ö. F., Arslan, Ç. Y., \& Eldemir, F. (2016). Third Party Logistics (3PL) Provider Selection with AHP Application. Procedia - Social and Behavioral Sciences, 235, 226-234. doi: 10.1016/j.sbspro.2016.11.018

Hamilton, J. (2009). Building a targeted pharmacy customer engagement approach. International Journal of Pharmaceutical and Healthcare Marketing, 3(4), 381-396.

Hamilton, R. T. (2011). How firms grow and the influence of size and age. International Small Business Journal, 30(6), 611-621. doi: 10.1177/0266242610383446

Harrigan, P., Evers, U., Miles, M. P., \& Daly, T. (2017). Customer engagement and the relationship between involvement, engagement, self-brand connection and brand usage intent. Journal of Business Research. doi: 10.1016/j.jbusres.2017.11.046

Hertwig, R., \& Pleskac, T. J. (2010). Decisions from experience: why small samples? Cognition, 115(2), 225-237. doi: 10.1016/j.cognition.2009.12.009

Hult, G. T. M., Ketchen Jr, D. J., \& Reus, T. H. (2001). Organizational learning capacity and internal customer orientation within strategic sourcing units. Journal of Quality Management, 6(2), 173-192. doi: http://dx.doi.org/10.1016/S1084-8568(01)00036-0

Hunt, S. D. (2013). A general theory of business marketing: R-A theory, Alderson, the ISBM framework, and the IMP theoretical structure. Industrial Marketing Management, 42(3), 283293. doi: 10.1016/j.indmarman.2013.02.002

Hunt, S. D. (2015). Marketing theory : foundations, controversy, strategy, resource-advantage theory. New York, USA: Routledge Taylor \& Francis Group.

Hunt, S. D., \& Morgan, R. M. (1995). The comparative advantage theory of competition. The Journal of Marketing, 1-15.

Ivanova, M., \& Ivanov, S. (2015). Affiliation to hotel chains: Hotels' perspective. Tourism Management Perspectives, 16, 148-162. doi: 10.1016/j.tmp.2015.08.001

Ivens, B. S., Pardo, C., Niersbach, B., \& Leischnig, A. (2016). Firm-internal key account management networks: Framework, case study, avenues for future research. Industrial Marketing Management, 58, 102-113. doi: 10.1016/j.indmarman.2016.05.019

Jangl, P. (2016). Model of Market Orientation of High-Tech Firms in Germany: Validation Study. Verslas: teorija ir praktika, 17(3), 216-224. doi: 10.3846/btp.2016.643

Järvinen, J., \& Karjaluoto, H. (2015). The use of Web analytics for digital marketing performance measurement. Industrial Marketing Management. doi: 10.1016/j.indmarman.2015.04.009

Javad Khazaei, P., Masood, K., \& Ezat Amirbakzadeh, K. (2017). Linking internal marketing orientation to balanced scorecard outcomes in small businesses: the case of travel agencies. International Journal of Culture, Tourism and Hospitality Research, 11(3), 297-308. doi: 10.1108/IJCTHR-03-2016-0024

Kang, E. S. L., \& Lam, S. Y. (2016). Contingent effects of firm and employee reputations on professional advice adoption. Service Business. doi: 10.1007/s11628-016-0312-7 
Kasper-Brauer, K., \& Leischnig, A. (2016). Yes, we can! A fuzzy-set analysis of challenges, skills, and enjoyment of work. Journal of Business Research, 69(11), 5286-5291. doi: 10.1016/j.jbusres.2016.04.126

Kianto, A., Sáenz, J., \& Aramburu, N. (2017). Knowledge-based human resource management practices, intellectual capital and innovation. Journal of Business Research, 81, 11-20. doi: 10.1016/j.jbusres.2017.07.018

Kim, D., Cavusgil, S. T., \& Cavusgil, E. (2013). Does IT alignment between supply chain partners enhance customer value creation? An empirical investigation. Industrial Marketing Management, 42(6), 880-889. doi: 10.1016/j.indmarman.2013.05.021

Kjos, A. L., Worley, M. M., \& Schommer, J. C. (2013). The social network paradigm and applications in pharmacy. Res Social Adm Pharm, 9(4), 353-369. doi: 10.1016/j.sapharm.2012.05.015

Kor, B. (2016). The mediating effects of self-leadership on perceived entrepreneurial orientation and innovative work behavior in the banking sector. Springerplus, 5(1), 1829. doi: 10.1186/s40064-016-3556-8

Krausert, A. (2017). HR differentiation between professional and managerial employees: Broadening and integrating theoretical perspectives. Human Resource Management Review, 27(3), 442457. doi: 10.1016/j.hrmr.2016.11.002

Kumar, N., \& Yakhlef, A. (2016). Managing business-to-business relationships under conditions of employee attrition: A transparency approach. Industrial Marketing Management, 56, 143-155. doi: 10.1016/j.indmarman.2016.01.002

Landers, R. N., Bauer, K. N., \& Callan, R. C. (2017). Gamification of task performance with leaderboards: A goal setting experiment. Computers in Human Behavior, 71, 508-515. doi: 10.1016/j.chb.2015.08.008

Landroguez, S. M. (2013). Developing an integrated vision of customer value. Journal of Services Marketing, 27(3), 234-244. doi: 10.1108/08876041311330726

Latham, G., Seijts, G., \& Slocum, J. (2016). The goal setting and goal orientation labyrinth. Organizational Dynamics, 45(4), 271-277. doi: 10.1016/j.orgdyn.2016.10.001

Latham, G. P. (2003). Goal Setting. Organizational Dynamics, 32(3), 309-318. doi: 10.1016/s00902616(03)00028-7

Latham, G. P. (2016). Goal setting: a possible theoretical framework for examining the effect of priming goals on organizational behavior. Current Opinion in Psychology, 12, 85-88. doi: 10.1016/j.copsyc.2016.07.005

Lee, M.-c. (2009). Factors Influencing the Adoption of Internet Banking: An Integration of TAM and TPB with Perceived Risk and Perceived Benefit. Electronic Commerce Research and Applications, 8(3), 130-141. doi: 10.1016/j.elerap.2008.11.006

Li, Y.-M. (2010). Pricing digital content distribution over heterogeneous channels. Decision Support Systems, 50(1), 243-257. doi: 10.1016/j.dss.2010.08.027 
ISSN 2582-2292

Vol. 3, No. 05 Sep-Oct; 2021

Locke, E. A. (1996). Motivation through conscious goal setting. Aplied \& Preventive Psychology, 5, 8.

Malik, A., Pereira, V., \& Budhwar, P. (2017). Value creation and capture through human resource management practices. Organizational Dynamics. doi: 10.1016/j.orgdyn.2017.09.002

Mathwick, C., Wagner, J., \& Unni, R. (2010). Computer-Mediated Customization Tendency (CMCT) and the Adaptive e-Service Experience. Journal of Retailing, 86(1), 11-21. doi: 10.1016/j.jretai.2009.11.001

Matošková, J., \& Směšná, P. (2017). Human resource management practices stimulating knowledge sharing. Management \& Marketing, 12(4). doi: 10.1515/mmcks-2017-0036

Mention, A.-L., \& Bontis, N. (2013). Intellectual capital and performance within the banking sector of Luxembourg and Belgium. Journal of Intellectual Capital, 14(2), 286-309. doi: $10.1108 / 14691931311323896$

Mitrega, M. (2012). Network partner knowledge and internal relationships influencing customer relationship

quality and company performance. Journal of Business \& Industrial Marketing, Vol. 27 / 6, pg. 486496. doi: 10.1108/08858621211251488

Mohamed, L. M. (2016). Assessing the effects of transformational leadership: A study on Egyptian hotel employees. Journal of Hospitality and Tourism Management, 27, 49-59. doi: 10.1016/j.jhtm.2016.04.001

Moharam, O. M., \& Shawky, A. Y. (2012). Measuring The Effects of Personalized Integrated Marketing Communication Tools on the Consumers" Intention to Purchase Credit Cards in the Private Banking Sector in Egypt. American Academic \& Scholarly Research Journal, 4(5), 114.

Mullen, J., Kelloway, E. K., \& Teed, M. (2017). Employer safety obligations, transformational leadership and their interactive effects on employee safety performance. Safety Science, 91, 405-412. doi: 10.1016/j.ssci.2016.09.007

Munir, R. I. S., Rahman, R. A., Malik, A. M. A., \& Ma'amor, H. (2012). Relationship between Transformational Leadership and Employees' Job Satisfaction among the Academic Staff. Procedia - Social and Behavioral Sciences, 65, 885-890. doi: 10.1016/j.sbspro.2012.11.215

Nahrgang, J. D., DeRue, D. S., Hollenbeck, J. R., Spitzmuller, M., Jundt, D. K., \& Ilgen, D. R. (2013). Goal setting in teams: The impact of learning and performance goals on process and performance. Organizational Behavior and Human Decision Processes, 122(1), 12-21. doi: 10.1016/j.obhdp.2013.03.008

Nicole, D., Vaughan, C., Zabihullah, S., \& Mei, L. (2016). Workplace training and generic and technical skill development in the Australian construction industry. Journal of Management Development, 35(4), 486-504. doi: 10.1108/JMD-05-2015-0073 
ISSN 2582-2292

Vol. 3, No. 05 Sep-Oct; 2021

Nor Shahriza Abdul, K., Mohamed Jalaldeen Mohamed, R., \& Norshidah, M. (2012). Measuring employee readiness for knowledge management using intention to be involved with KM SECI processes. Business Process Management Journal, 18(5), 777-791. doi: $10.1108 / 14637151211270153$

Obal, M., \& Lancioni, R. A. (2013). Maximizing buyer-supplier relationships in the Digital Era: Concept and research agenda. Industrial Marketing Management, 42(6), 851-854. doi: 10.1016/j.indmarman.2013.06.002

Ouakouak, M. L., \& Ouedraogo, N. (2017). ANTECEDENTS OF EMPLOYEE CREATIVITY AND ORGANISATIONAL INNOVATION: AN EMPIRICAL STUDY. International Journal of Innovation Management, 21(07), 1750060. doi: 10.1142/S1363919617500608

Pittino, D., Visintin, F., Lenger, T., \& Sternad, D. (2016). Are high performance work practices really necessary in family SMEs? An analysis of the impact on employee retention. Journal of Family Business Strategy, 7(2), 75-89. doi: 10.1016/j.jfbs.2016.04.002

Poisson-de Haro, S., \& Bitektine, A. (2015). Global sustainability pressures and strategic choice: The role of firms' structures and non-market capabilities in selection and implementation of sustainability initiatives. Journal of World Business, 50(2), 326-341. doi: 10.1016/j.jwb.2014.10.009

Rakesh, S., Narendra, K., \& Sandeep, P. (2017). Thought self-leadership strategies and sales performance: Integrating selling skills and adaptive selling behavior as missing links. Journal of Business \& Industrial Marketing. doi: 10.1108/JBIM-06-2016-0127

Raybould, M., \& Wilkins, H. (2006). Generic Skills for Hospitality Management: A Comparative Study of Management Expectations and Student Perceptions. Journal of Hospitality and Tourism Management, 13(2), 177-188. doi: 10.1375/jhtm.13.2.177

Reid, M., \& Brady, E. (2012). Improving firm performance through NPD: The role of market orientation, NPD orientation and the NPD process. Australasian Marketing Journal (AMJ), 20(4), 235-241. doi: 10.1016/j.ausmj.2012.05.011

Sambasivan, M., Abdul, M., \& Yusop, Y. (2009). Impact of personal qualities and management skills of entrepreneurs on venture performance in Malaysia: Opportunity recognition skills as a mediating factor. Technovation, 29(11), 798-805. doi: 10.1016/j.technovation.2009.04.002

Samson, D., Gloet, M., \& Singh, P. (2017). SYSTEMATIC INNOVATION CAPABILITY: EVIDENCE FROM CASE STUDIES AND A LARGE SURVEY. International Journal of Innovation Management, 21(07), 1750058. doi: 10.1142/S136391961750058X

Senichev, V. (2013). Human Resource Diversity and Performance within the Frame of Organizations, Teams and Individuals. Verslas: teorija ir praktika, 14(4), 337-345. doi: 10.3846/btp.2013.36

Silva, R., Gerwe, O., \& Becerra, M. (2017). Corporate brand and hotel performance: A resource-based perspective. Journal of Business Research, 79, 23-30. doi: 10.1016/j.jbusres.2017.05.019 
ISSN 2582-2292

Vol. 3, No. 05 Sep-Oct; 2021

Stan De, S., Monique, R., \& Guy Van, G. (2017). Good employees through good jobs: A latent profile analysis of job types and employee outcomes in the Belgian electricity sector. Employee Relations, 39(4), 503-522. doi: 10.1108/ER-02-2016-0034

Stock, R. M. (2016). Understanding the relationship between frontline employee boreout and customer orientation. Journal of Business Research, 69(10), 4259-4268. doi: 10.1016/j.jbusres.2016.02.037

Stone, D. L., Deadrick, D. L., Lukaszewski, K. M., \& Johnson, R. (2015). The influence of technology on the future of human resource management. Human Resource Management Review, 25(2), 216-231. doi: 10.1016/j.hrmr.2015.01.002

Stundziene, A., Startiene, G., Remeikiene, R., \& Dapkus, M. (2015). Does the Survey Data on New Orders Lie? Procedia - Social and Behavioral Sciences, 213, 5-11. doi: 10.1016/j.sbspro.2015.11.395

Susilo, W. H. (2016). An Impact of Behavioral Segmentation to Increase Consumer Loyalty: Empirical Study in Higher Education of Postgraduate Institutions at Jakarta. Procedia - Social and Behavioral Sciences, 229, 183-195. doi: 10.1016/j.sbspro.2016.07.128

Susilo, W. H. (2020a). Business Research Methods: Market Based Managment Approach in Apllication (S. I. I. Group Ed. First Edition ed.). Bogor, INA: IN MEDIA.

Susilo, W. H. (2020b). The Business Research: The Competency \& Confident- Building Approach (imuruz Ed.). Mauritius: LAMBERT Academic Publishing.

Syed Saad, A., Mamunur, R., \& Quazi Akhlaqur, R. (2016). A model of customer-centric banking practices for corporate clients in Bangladesh. International Journal of Bank Marketing, 34(4), 458-475. doi: 10.1108/IJBM-10-2014-0156

Szopiński, T. S. (2016). Factors affecting the adoption of online banking in Poland. Journal of Business Research, 69(11), 4763-4768. doi: 10.1016/j.jbusres.2016.04.027

Thomas, E. (2013). Supplier integration in new product development: Computer mediated communication, knowledge exchange and buyer performance. Industrial Marketing Management, 42(6), 890-899. doi: 10.1016/j.indmarman.2013.05.018

Tse, H. H. M., Huang, X., \& Lam, W. (2013). Why does transformational leadership matter for employee turnover? A multi-foci social exchange perspective. The Leadership Quarterly, 24(5), 763-776. doi: 10.1016/j.leaqua.2013.07.005

Ulum, I., Ghozali, I., \& Purwanto, A. (2014). Intellectual Capital Performance of Indonesian Banking Sector: A Modified VAIC (M-VAIC) Perspective. Asian Journal of Finance \& Accounting, 6(2), 103. doi: 10.5296/ajfa.v6i2.5246

Vos, F. G. S., Schiele, H., \& Hüttinger, L. (2016). Supplier satisfaction: Explanation and out-ofsample prediction. Journal of Business Research, 69(10), 4613-4623. doi: 10.1016/j.jbusres.2016.04.013 
Walmsley, B. (2016). From arts marketing to audience enrichment: How digital engagement can deepen and democratize artistic exchange with audiences. Poetics, 58, 66-78. doi: 10.1016/j.poetic.2016.07.001

Wang, C.-J., Tsai, H.-T., \& Tsai, M.-T. (2014). Linking transformational leadership and employee creativity in the hospitality industry: The influences of creative role identity, creative selfefficacy, and job complexity. Tourism Management, 40, 79-89. doi: 10.1016/j.tourman.2013.05.008

Wang, Z., Sharma, P. N., \& Cao, J. (2016). From knowledge sharing to firm performance: A predictive model comparison. Journal of Business Research, 69(10), 4650-4658. doi: 10.1016/j.jbusres.2016.03.055

Welsh, D., Bush, J., Thiel, C., \& Bonner, J. (2019). Reconceptualizing goal setting's dark side: The ethical consequences of learning versus outcome goals. Organizational Behavior and Human Decision Processes, 150, 14-27. doi: 10.1016/j.obhdp.2018.11.001

Welsh, D. T., \& Ordóñez, L. D. (2014). The dark side of consecutive high performance goals: Linking goal setting, depletion, and unethical behavior. Organizational Behavior and Human Decision Processes, 123(2), 79-89. doi: 10.1016/j.obhdp.2013.07.006

Xerri, M. J., \& Reid, S. R. M. (2017). HUMAN RESOURCES AND INNOVATIVE BEHAVIOUR: IMPROVING NURSING PERFORMANCE. International Journal of Innovation Management, 1850019. doi: 10.1142/S1363919618500196

Xiaohong, Z., Chengfeng, L., Yanbo, W., \& Gaowen, T. (2015). The impact of employees' relationships on tacit knowledge sharing. Chinese Management Studies, 9(4), 611-625. doi: 10.1108/CMS-06-2015-0126

Xu, S., Wang, Y.-C., \& Wen, H. (2019). A case study for student leadership development: A goal setting perspective. Journal of Hospitality, Leisure, Sport \& Tourism Education, 24, 168-177. doi: 10.1016/j.jhlste.2019.03.001

Zhao, G., Feng, T., \& Wang, D. (2015). Is more supply chain integration always beneficial to financial performance? Industrial Marketing Management, 45, 162-172. doi: 10.1016/j.indmarman.2015.02.015 